\title{
Large- and small-mammal distribution patterns and chronostratigraphic boundaries from the Late Pliocene to the Middle Pleistocene of the Italian peninsula
}

\author{
Federico Masini ${ }^{\mathrm{a}, *}$, Benedetto Sala ${ }^{\mathrm{b}}$ \\ ${ }^{a}$ Dipartimento di Geologia e Geodesia, Università di Palermo, Via Archirafi 22, 90123 Palermo, Italy \\ ${ }^{\mathrm{b}}$ Dipartimento delle Risorse Naturali e Culturali, Università di Ferrara, C.so Ercole I D'Este, 32, 44100 Ferrara, Italy
}

Available online 19 December 2006

\begin{abstract}
Over the last 50 years the studies on terrestrial mammals of the Italian peninsula have provided a large volume of data and a more detailed knowledge of faunal events during the Late Pliocene and Quaternary. Moreover geological, sedimentological, palynological and magnetostratigraphical investigations on the Pliocene-Pleistocene continental sedimentary basins have yielded the possibility of a detailed calibration of the faunal successions. Thus, palaeontologists have been able to reconstruct faunal sequences and to propose biochronological scales based on large and small mammals, respectively. In the present contribution an integration of the two biochronological scales is proposed, and the successions of bioevents are carefully compared. This integrated approach allows the constraint of the sequence of large- and small-mammal events in a more reliable way, and therefore it results in a more detailed and consistent chronological use of mammalian assemblages. Particular attention is paid to the faunal changes that correspond to the Middle-Late Pliocene (2.6 ma), Pliocene-Pleistocene (1.8 ma) and Early-Middle Pleistocene (Gauss-Matuyama transition) chronostratigraphical boundaries.
\end{abstract}

(C) 2006 Elsevier Ltd and INQUA. All rights reserved.

\section{Introduction}

The Italian mammal chronology has been developed since the pioneering work of Azzaroli in the 1970s mainly on the basis of large-sized mammalian taxa. The Mammal Age (sensu Lindsay, 1990) names 'Villafranchian' and 'Galerian', although sometimes criticised, are widespread concepts used by the scientific community of continental stratigraphers in Southern Europe. In more recent years, thanks to the discovery of important new localities and the careful sieving of many fluviolacustrine deposits in Italy, small mammal stratigraphy is becoming of age. Italian micromammal students tend to refer to biochronological scales widely adopted in the European countries, instead of developing local units (Sala and Masini, 2004, 2006). The two biochronological sequences, apart from in some sporadic cases, are often treated as distinct. This is also

\footnotetext{
*Corresponding author. Fax: + 390917041041.

E-mail address: fmasini@unipa.it (F. Masini).
}

because the specialists in one group are often not very confident with knowledge from another.

The different body size that distinguishes the 'large' from the 'small' mammals also coincides with different clusters of taxonomic groups and has a two-fold influence. First, the two categories have a different taphonomy, which influences their distribution and recovery and the methods required during collection. Secondly, their size influences their evolutionary and dispersal behaviour and consequently the stratigraphical distribution of the two groups. Large mammals are less limited by local microclimatic and microenvironmental conditions; they are able to make more frequent and rapid dispersals, and therefore they apparently produce quicker turnover in the stratigraphical record. Small-sized mammals, on the other hand, are more strongly influenced by microenvironmental conditions, and, are in general more static in evolutionary terms and their turnover behaviour. During the Pliocene-Pleistocene, noticeable exceptions are the very dynamic sub-family Arvicolinae, and the shrews. 
Here, the authors present an integrated biochronological framework for large and small mammals to obtain a finer resolution and a more reliable control of the succession of faunal events. This framework has been integrated into a chronostratigraphical scheme by means of radiometric and magnetostratigraphical calibration and marine-continental correlations available from several sites (Fig. 1).

A consistent marine stratigraphical record occurs in the Neogene and Quaternary of Italy, so that several Global Stratotype Section and Point (GSSP) have been proposed from the peninsula (Rio et al., 2003). In the Miocene, the terrestrial mammalian record is predominantly insular and/ or endemic: e.g. Scontrone (Molise), various localities in Maritime Tuscany (Tuscany), Sardinia (Mazza and Rustioni, 1996; Rook et al., 1999, 2000) (Fig. 2). Following the Messinian phase, documented by the localities of Gravitelli (Sicily), Brisighella (Emilia Romagna), Ciabot Cagna (Piedmont) (De Giuli and Vai, 1988; Cavallo et al., 1993) when no endemic faunas spread into the whole peninsula (Fig. 2), the Early Pliocene fossil mammal record becomes rather scant (Azzaroli et al., 1988). However, it is abundant and well known from the Middle Pliocene (Azzaroli et al.,
1988; Masini et al., 1995; Gliozzi et al., 1997; Kotsakis et al., 2003) (Fig. 2).

The aim of this paper is to present and discuss the faunal events that occurred close to three chronostratigrafic boundaries: Middle-Late Pliocene (Rio et al., 1994, 1998), Pliocene-Pleistocene (Aguirre and Pasini, 1985) and Early-Middle Pleistocene. The latter boundary is still under discussion by the scientific community. In the last years the proposal of Richmond (1996) to place the Early-Middle Pleistocene boundary at the Brunhes-Matuyama magnetic reversal epoch boundary has found consideration by Quaternary researchers (cf. Gibbard and van Kolfschoten, 2004), but also other proposals have been recently presented (e.g. Ciaranfi et al., 1997; Capraro et al., 2004; Ciaranfi et al., 2004; Ciaranfi and D'Alessandro, 2005). In this paper the proposal of Richmond (1996) is taken under consideration.

\section{Middle Pliocene-Late Pliocene transition: Early-Middle Villafranchian, and the Early Villanyian}

After the Messinian faunas of the MN13 zone, the record of fossil mammals becomes rather poor in the

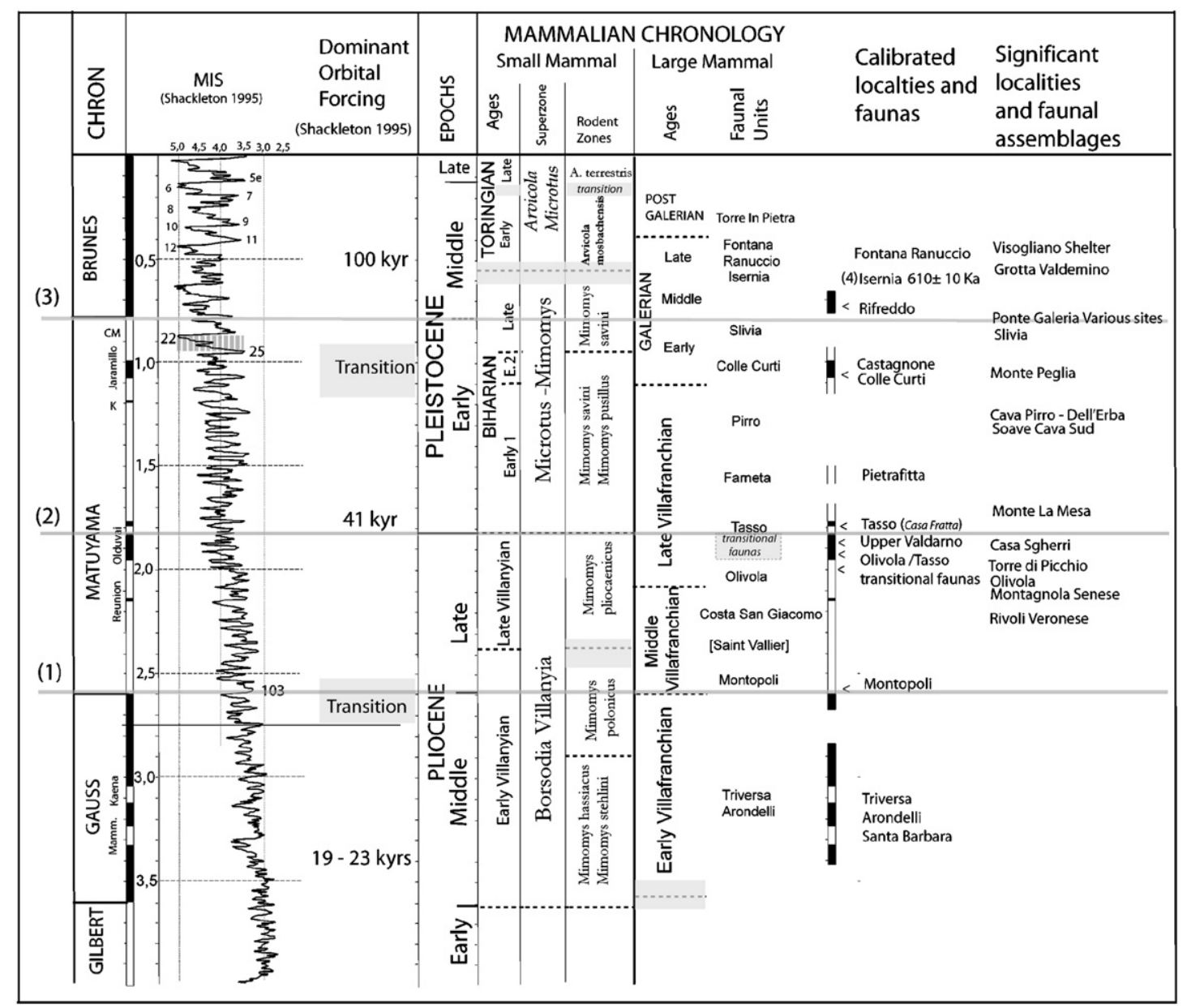

Fig. 1. Integrated stratigraphic scheme for the Middle Pliocene-Pleistocene large- and small-mammalian record of the Italian peninsula. The grey lines indicate the position of the chronostratigraphic boundaries discussed in the text: 1. Middle-Late Pliocene boundary (Rio et al., 1994, 1998). 2. Pliocene-Pleistocene boundary (Aguirre and Pasini, 1985). 3. Early-Middle Pleistocene boundary according to the proposal of Richmond (1996). 4. Isernia ${ }^{40} \mathrm{Ar} /{ }^{39} \mathrm{Ar}$ dating according to Coltorti et al. (2005). 


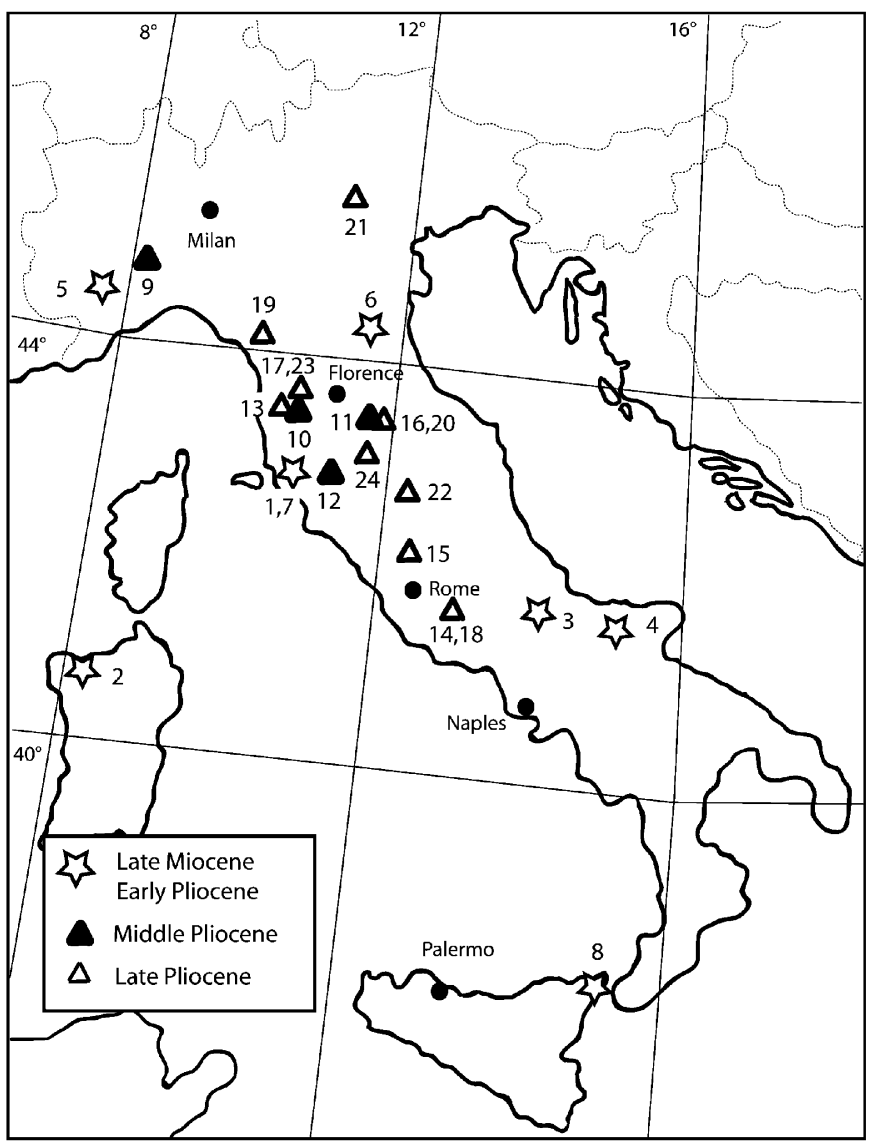

Fig. 2. Location map. 1-8: Late Miocene-Early Pliocene localities. 1. Maritime Tuscany (Grosseto, Tuscany), various sites, Late Miocene endemic fauna of the Tuscany-Sardinian palaeobioprovince (after Rook et al., 1999). 2. Fiume Santo (Sardinia), Late Miocene, endemic fauna of the Tuscany-Sardinian palaeobioprovince. 3. Scontrone (Abruzzi), Late Miocene endemic fauna of the Apulia-Abruzzi palaeobioprovince. 4. Gargano 'terre rosse' fissure fillings (Apricena, Apulia), Late Miocene (?) -Early Pliocene endemic fauna of the Apulia-Abruzzi palaeobioprovince. 5. Ciabot Cagna (Alba, Piedmont), Messinian continental fauna. 6 . Cava Monticino (Brisighella, Faenza, Emilia Romagna), Late Messinian continental fauna. 7. Maritime Tuscany (Grosseto, Tuscany), various sites, Messinian, continental fauna. 8. Gravitelli (Messina, Sicily), Messinian continental fauna of African affinity (Rook et al., 1999, 2000). 9-12: Middle Pliocene localities. 9. Villafranca D'Asti (Asti, Piedmont): Triversa, Fornace RDB, Cascina Arondelli Quarry. 10. Lower Valdarno (Tuscany), several localities with Early Villafranchian-Early Villanyan faunas, among which San Giusto-type locality of Mimomys stehlini. 11. Upper Valdarno Basin (Arezzo, Tuscany), Lower Synthem: Castelnuovo dei Sabbioni, Santa Barbara and other localities. 12. Arcille (Grosseto, Tuscany). 13-24: Late Pliocene localities. 13. Montopoli (Lower Valdarno Basin, Pisa, Tuscany). 14. Collepardo (Anagni Basin, Frosinone, Latium). 15. Bocchignano (Rieti, Latium). 16. Upper Valdarno Basin (Arezzo, Tuscany), Mimomys polonicus find. 17. Vinci (Lower Valdarno Basin, Florence, Tuscany). 18. Costa San Giacomo (Anagni Basin, Frosinone, Latium). 19. Olivola (Aulla Basin, La Spezia, Tuscany). 20. Upper Valdarno Basin (Tuscany), several localities with Late Villafranchian large-mammal fauna (Olivola FU) and Castelfranco di Sopra (type locality of Mimomys pliocaenicus). 21. Rivoli Veronese (Verona). 22. Torre di Picchio (Tiberino Basin, Terni, Latium). 23. Casa Sgherri (Lower Valdarno Basin, Florence, Tuscany). 24. Montagnola Senese (Siena,Tuscany).
Italian peninsula. The first significant record after the Ruscinian gap is given by the Early Villafranchian faunas of the Triversa Faunal Unit (FU) and by the related Early Villanyian small mammals of Mimomys hassiacusMimomys stehlini zone, whose best record is at Cascina Arondelli (Piedmont) and at Arcille, near the town of Grosseto (Tuscany) (Berzi et al., 1967; Michaux, 1970; Azzaroli, 1977; Azzaroli et al., 1988; Fejfar, 2001) (Figs. 2-4).

These mammalian assemblages still retain the subtropical affinities, which were typical of the Ruscinian Mammal Age. They include many taxa with moist forest affinities (e.g. Tapirus, Mammut borsoni, Anancus arvernensis, Sus minor, Mesopithechus, Parailurus, Blarinoides, flying squirrels) to which are associated new mammals, perhaps more linked to wooded parkland environment (e.g. the large-sized antelope Leptobos stenometopon, Stephanorhinus elatus, the medium-sized deer Pseudodama lyra). The occurrence of the sabre-tooth cat Homotherium and of the cheetah Acinonyx pardinensis, are also important (Fig. 3). The cooccurrence of two stratigraphic marker taxa, Mammut borsoni and Anancus arvernensis, allow a fairly precise correlation with the European regions. These faunas occur in Piedmont, west of the town of Asti, along the western and southern side of Tuscany (Lower Valdarno basin, several localities) where they are superposed to marine sediments, and in the Lower Synthem of the Upper Valdarno Basin (Castelnuovo Synthem; Fig. 2). They are assigned to the Gauss Chron (Torre et al., 1996; Napoleone et al., 2003; Ghinassi et al., 2004).

The next significant large-mammal assemblage is that from Montopoli in the Lower Valdarno (Tuscany; Fig. 2), where it is stratigraphically superposed on faunas of Triversa unit and to shallow-water marine sediments of Middle Pliocene age (Benvenuti et al., 1995). This fauna, and the related faunal unit, occur at the Gauss-Matuyama transition (Lindsay et al., 1980) and provides an important signal of environmental change for the dispersals of the genus Mammuthus (with the primitive form M. meridionalis gromovi), the horse (Equus cf. livenzovensis), the 'giant deer' Eucladoceros, and of a Gazella (G. borbonica) (Fig. 3). The thar (Hemitragus) is also recorded for the first time in Italy at Collepardo (Anagni Basin, Frosinone; Fig. 2) a local fauna belonging to this unit, although it is perhaps slightly younger than the Montopoli fauna.

This faunal unit apparently corresponds to the upper part of the MN16b zone and was traditionally included in the Early Villafranchian (e.g. Azzaroli et al., 1988). Following the opinion of De Giuli et al. (1984) and Palombo et al. (2002), the authors are inclined here to consider it as the basal unit of the Middle Villafranchian, since the 'open environment' taxa, the dispersals of which are recorded at Montopoli, persist in the Middle Villafranchian faunas.

The Montopoli FU is correlated with the upper part of the Mimomys polonicus zone (Fig. 1). The documentation of this zone is very poor in Italy. A sporadic find 


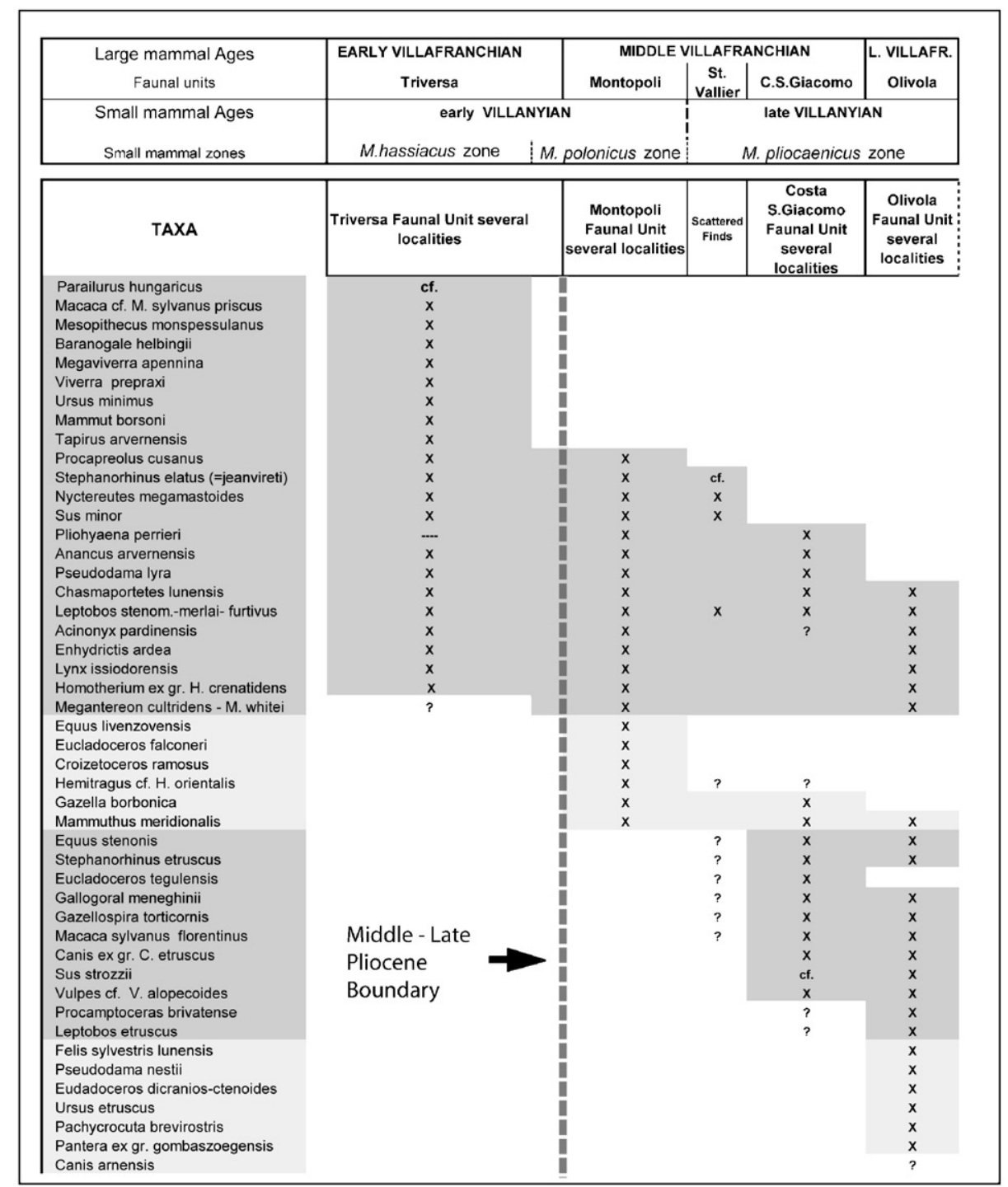

Fig. 3. Distribution pattern of large-mammalian faunal units and taxa of the Early and Middle Villafranchian in the Italian peninsula. The correlation with small-mammal biochronological units is also indicated. The Middle-Late Pliocene boundary is according to Rio et al. (1994, 1998). X, occurrence; - , rare occurrence;?, doubtful or questioned occurrence.

of M. polonicus comes from Bocchignano (Latium; Petronio et al., 2002, Kotsakis et al., 2003; Fig. 2), without correlation with large-mammal faunas. The recent find of an advanced $M$. polonicus in the Upper Valdarno Basin, in a succession correlated to early Matuyama (Ghinassi et al., 2004, 2005), corroborates that the M. polonicus zone includes also the Montopoli faunal zone in the Italian peninsula. This is also suggested by the occurrence of Germanomys sp. in the Vinci locality (Lower Valdarno; Fig. 2), in sediments referred to the Late Pliocene (Marcolini et al., 2000; Marcolini, 2003; Sardella et al., 2003) (Fig. 4). The Germanomys find is here tentatively correlated to the $M$. polonicus zone. However, a possible correlation of the Vinci locality with the younger Costa San Giacomo FU has been suggested by the previous authors, based on the occurrence of a single horse molar tentatively referred to Equus senezensis or to Equus stenonis.
The faunal renewal of the Middle-Villafranchian falls close to the Middle-Late Pliocene boundary (Gelasian Stage, GSSP at Monte san Nicola Section, Sicily; Rio et al., 1994; Gradstein et al., 2004). It correlates to the effects of the transition to a climate in which moderately increased glacial-interglacial fluctuations alternated, influenced by the $41 \mathrm{ka}$ orbital cycle of the obliquity variation (Shackleton, 1995) (Fig. 1). This boundary is the starting point of a progressive global climate deterioration that affects the vegetational composition and consequently the fauna.

The St. Vallier FU, the second unit of the Middle Villafranchian is recorded in Italy by some sporadic finds, while a better record is given by the Costa San Giacomo FU (Anagni Basin, Latium). The faunal composition is very similar to that of the preceding unit, important first occurrences, however, are those of the rhinoceros Stephanorhinus etruscus, the horse E. stenonis, a large-sized boar Sus cf. strozzii, the rupicaprine Gallogoral, and the spiral 


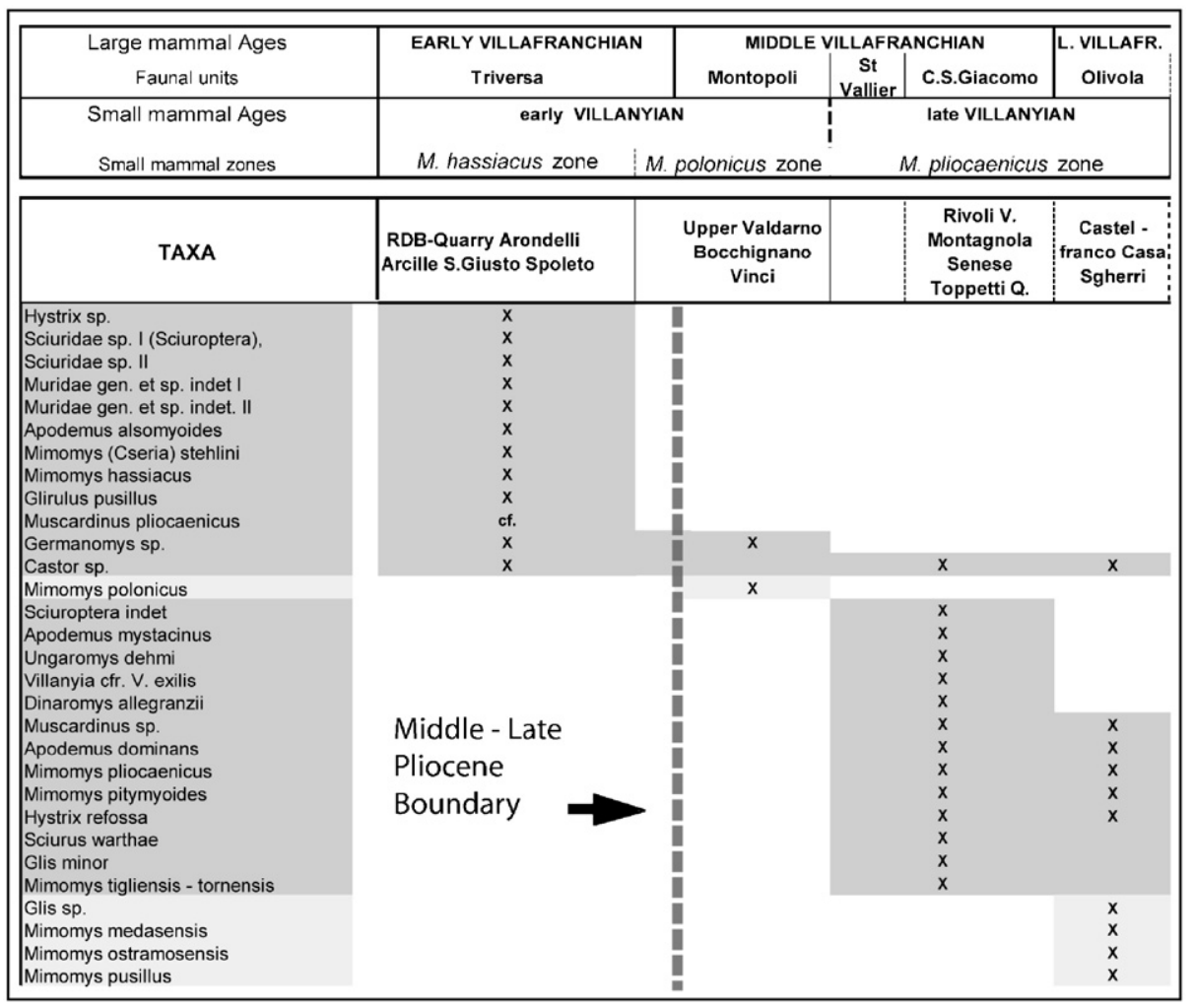

Fig. 4. Distribution pattern of rodent taxa for the Villanyian Mammal Age of the Italian peninsula. The correlation with large-mammal biochronological units is also indicated. The Middle-Late Pliocene boundary is according to Rio et al. (1994, 1998). Explanations of symbols as in Fig. 3.

horned antelope Gazellospira. The mastodon Anancus and the genus Gazella are recorded for the last time. The sporadic occurrence of a relative of the modern wolf, Canis cf. etruscus, very common in the following units, is an important event among carnivores (Rook and Torre, 1996) (Fig. 3).

The first faunal unit of the Late Villafranchian, the Olivola FU, records a further change in faunal composition that yet it retains continuity. In this unit the gregarious 'antelope' Leptobos etruscus becomes the most widespread bovid, and derived forms of deer (Eucladoceros dicranios-ctenoides, Pseudodama nestii) appear. It is also worth mentioning the occurrence of the Caprinae Procamptoceras. The presence, among the carnivores, of the large, social, spotted hyaena Pachycrocuta brevirostris and the jaguar-like Panthera gombaszoegensis are also important.

Local faunas of the Olivola FU and faunas transitional to the next unit, the Tasso FU, are rather common in the Upper Valdarno Basin and represent the bulk of finds in older and more recent collections (Figs. 2 and 5). Magnetic investigations have allowed the correlation of these faunas to an interval that extends from the reverse polarity Matuyama Chron above the Reunion Event and the greater part of the Olduvai Subchron (Torre et al., 1993; Napoleone et al., 2003).

Considering the small mammal faunas, following the poorly represented M. polonicus zone, the Late Villanyian Mimomys pliocaenicus zone is fairly represented in Italy.
Rivoli Veronese (Venetia; Sala et al., 1994; Sala, 1996b; Sala and Masini, 2006) is the most important local fauna and, because it includes a rather primitive M. pliocaenicus, is considered the oldest record of this zone. Some other faunas are known in the Italian peninsula in which M. pliocaenicus or Mimomys ostramosensis are present (Figs. 2 and 4).

The occurrence of the type specimen of $M$. pliocaenicus (actually a derived morphotype) at locality Castelfranco di Sopra (Fig. 2) in the Upper Valdarno Basin is an element for correlation with the large-mammal succession. Here, sediments that have yielded large mammals of the Olivola FU or transitional to the Tasso FU are exposed (Masini and Torre, 1987; Mazza et al., 2004). Mimomys medasensis and $M$. ostramosensis have also been recently found in association with large mammals of the Olivola and Costa San Giacomo FU: Torre di Picchio, in the Tiberino Basin (Marcolini, 2002) and Casa Sgherri in Lower Valdarno (Marcolini et al., 2000; Girotti et al., 2003) (Fig. 2).

In short, the M. pliocaenicus zone is directly correlated with the Costa San Giacomo, Olivola and the transitional Olivola-Tasso Faunal Units (Fig. 1). The lack of small mammals finds from the localities of the older part of the Middle Villafranchian prevents a more accurate correlation. This gap in the record results in the small mammals of the $M$. pliocaenicus zone being markedly different in comparison to the Older Arondelli and coeval faunas (Fig. 4). Among the arvicolids, additional characteristic 
taxa include Mimomys tornensis and Mimomys pitymyoides, which were widespread in the northern and central part of the peninsula. The survival of Prolagus into this unit is also significant. This Ochotonid was rather common in the central Italian basins, and the dominant taxa in the karstic deposit at Montagnola Senese. The unique occurrence of Apodemus mystacinus, the first occurrences of Apodemus dominans among the murids, of Oryctolagus lacosti within lagomorphs, and finally of Crocidura and Sorex runtonensis among insectivores are also noteworthy.

The Rivoli Veronese fauna (Sala et al., 1994) is especially important, since it includes the highest taxonomic diversity in the rodents and insectivores. This fauna yields the unique occurrences in Italy of Ungaromys dehmi and of the Villanyia genus and the first occurrence of the genus Dinaromys, with the primitive species Dinaromys allegranzii (Sala, 1996b). D. allegranzii is the oldest known species of this genus, which later spread mainly into the Balkan and the northern Italian regions.

\section{Pliocene-Pleistocene boundary: the Olivola-Tasso and Villanyian-Biharian transitions}

The transition from the Olivola to the subsequent Tasso FU is known from the Upper Valdarno Basin, where fossilbearing sediments from the two stratigraphically superposed units are exposed (Torre, 1985; Masini and Torre, 1987; Azzaroli et al., 1988). This transition has been correlated magnetostratigraphically close to the top of the Olduvai Subchron (Napoleone et al., 2003), which is around the basal Pleistocene boundary (GSSP at La Vrica Section; Aguirre and Pasini, 1985; Albianelli et al., 2002, Gradstein et al., 2004) (Fig. 1). This boundary is placed within an interval of gradual climatic transition which mirrors the gradual change in faunal composition.

The Tasso FU includes some novel elements, such as the occurrence of Praeovibos (locality Casa Frata), of a primitive lycaon (Lycaon falconeri), of a derived form of medium-sized deer (Pseudodama eurygonos-farnetensis), of the small equid Equus stehlini, and of Leptobos vallisarni, a stouter relative of L. etruscus. This assemblage also includes the last occurrence on the Italian mainland of the genus Prolagus (Upper Valdarno; Rook and Masini, 1990), while the bovids Gazellospira and Procamptoceras are no longer present. The occurrence of Hippopotamus in this unit is doubtful, even though it is present at Carsoli (Anagni Basin, Latium), together with Leptobos aff. furtivus (Masini, 1989; Gentili and Masini, 2005) (Figs. 5, 6).

The finds of Mimomys savini in two localities of the Upper Valdarno (Le Strette al Tasso and Case Inferno; Fig. 5) in sediments which according to Torre (1985) and Masini and Torre (1987) are considered as the reference for the Tasso FU suggest that this unit can be correlated with the Early Biharian (Figs. 1 and 7). It is worth mentioning, however, that no remains of Microtus (Allophaiomys) have

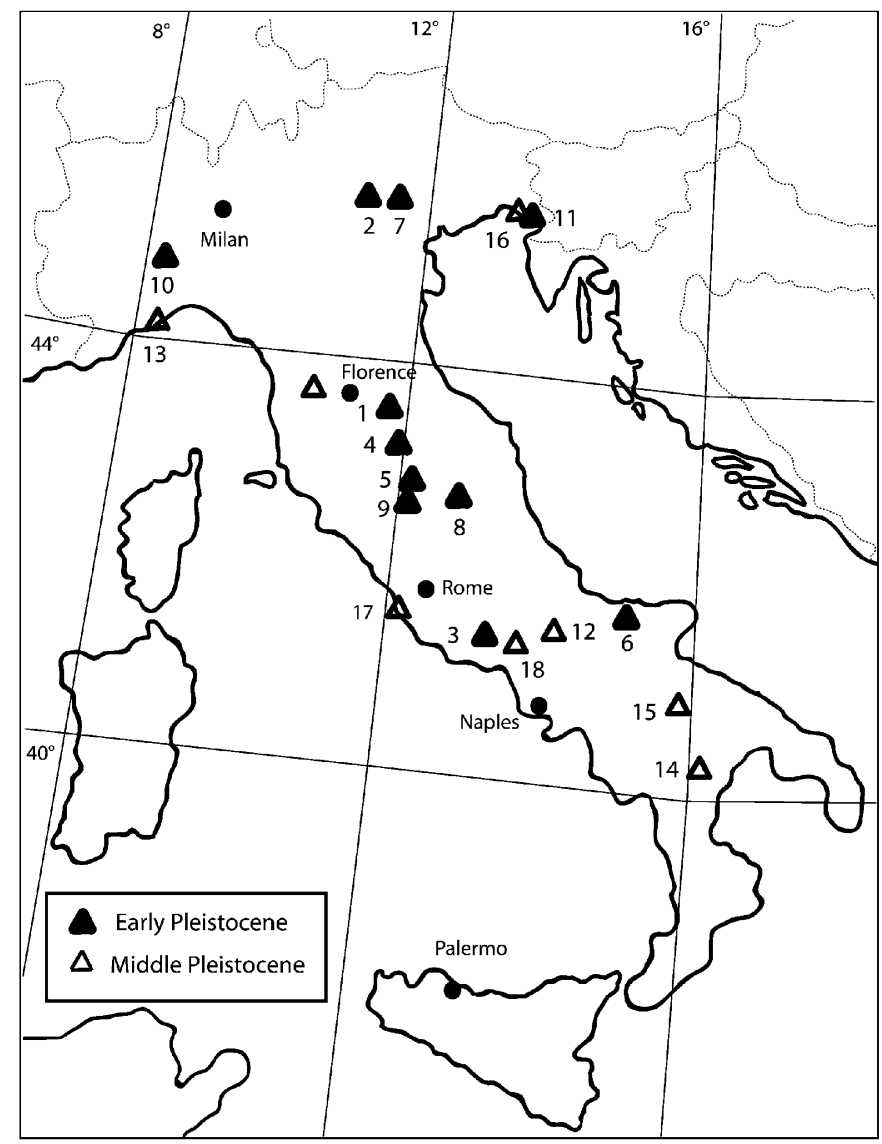

Fig. 5. Location map. Early Pleistocene-Middle Pleistocene (early part) localities. 1. Upper Valdarno Basin (Arezzo, Tuscany): Il Tasso, Casa Frata, Le Strette al Tasso, Case Inferno and other localities. 2. Monte La Mesa (Verona, Venetia). 3. Carsoli, (Anagni Basin, Frosinone, Latium). 4. Val di Chiana, (Arezzo, Tuscany): Farneta, Cava Liberatori, Selvella and other localities. 5. Pietrafitta, (Nestore Basin, Perugina, Umbria). 6. Cava Pirro (Gargano, Foggia, Apulia). 7. Soave Cava Sud (Verona, Venetia). 8. Colle Curti (Umbro Marchean Apennine). 9. Monte Peglia (Perugina, Umbria). 10. Castagnone (Alessandria, Piedmont). 11. Slivia (Trieste, Venetia Giulia). 12. Isernia La Pineta (Isernia, Molise). 13. Valdemino Cave (Savona, Liguria). 14. Rifreddo (Sant'Arcangelo Basin, Potenza, Basilicata). 15. Venosa Notarchirico (Potenza, Basilicata). 16. Visogliano Shelter (Trieste, Venetia Giulia). 17. Ponte Galeria (Rome, Latium): Fontignano, Ponte Galeria 2 and several other localities. 18. Fontana Ranuccio (Anagni Basin, Frosinone, Latium).

so far been found in the Late Villafranchian horizons of the Upper Valdarno Basin.

The most representative locality of the Early Biharian in Italy is Monte La Mesa (Venetia region), where a very rich and diverse small-mammal assemblage has been recovered (Marchetti et al., 2000). The occurrence of a typical Microtus (Allophaiomys) pliocaenicus, in association with M. cf. ostramosensis and Mimomys pusillus, allows it to be considered as the oldest Biharian assemblage in Italy. It is tentatively correlated to the Tasso unit. The Monte La Mesa assemblage records several significant occurrences: those of the genera Allocricetus and Clethrionomys, of Pliomys episcopalism among the rodents, of Sorex minutus and Sorex prealpinus among insectivores. Mimomys cf. 


\begin{tabular}{|c|c|c|c|c|c|}
\hline \multirow{2}{*}{$\begin{array}{c}\text { Large mammal Ages } \\
\text { Faunal units }\end{array}$} & \multirow{2}{*}{\begin{tabular}{|c|} 
M.VILL. \\
C.S.Giacomo \\
\end{tabular}} & \multirow[b]{2}{*}{ Olivola } & \multicolumn{3}{|c|}{ LATE VILLAFRANCHIAN } \\
\hline & & & Tasso & Farneta & Pirro \\
\hline $\begin{array}{l}\text { Small mammal Ages } \\
\text { Small mammal zones }\end{array}$ & \multicolumn{2}{|c|}{ late VILLANYIAN } & \multicolumn{3}{|c|}{$\begin{array}{c}\text { BIHARIAN } \\
\text { Early Biharian I } \\
\text { M.pusillus - M.savini zone }\end{array}$} \\
\hline TAXA & $\begin{array}{c}\text { Costa } \\
\text { S.Giacomo } \\
\text { Faunal Unit } \\
\text { several } \\
\text { localities }\end{array}$ & $\begin{array}{c}\text { Olivola Faunal } \\
\text { Unit } \\
\text { several } \\
\text { localities }\end{array}$ & $\begin{array}{c}\text { Tasso } \\
\text { Faunal Unit } \\
\text { several } \\
\text { localities }\end{array}$ & $\begin{array}{c}\text { Farneta } \\
\text { Faunal } \\
\text { Unit } \\
\text { several } \\
\text { localities }\end{array}$ & $\begin{array}{l}\text { Pirro } \\
\text { Faunal Unit } \\
\text { several } \\
\text { localities }\end{array}$ \\
\hline Hemitragus cf. $\mathrm{H}$. orientalis & $?$ & & & & \\
\hline Pliohyaena perrieri & $\mathrm{x}$ & ] & & & \\
\hline Anancus arvernesis & $x$ & 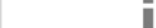 & & & \\
\hline Pseudodama lyra & $x$ & 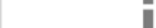 & & & \\
\hline Gazella borbonica & $x$ & 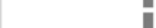 & & & \\
\hline Eucladoceros tegulensis & $x$ & & & & \\
\hline Chasmaportetes lunensis & $\mathrm{x}$ & $\mathrm{x}$ & & & \\
\hline Gazellospira torticornis & $\mathrm{x}$ & $\mathrm{x}$ & & & \\
\hline Gallogoral meneghinii & $\mathrm{x}$ & $\hat{x}$ & & & \\
\hline Procamptoceras brivatense & $?$ & $x$ & ? & & \\
\hline Acinonyx pardinensis & ? & $x$ & $\mathrm{x}$ & & \\
\hline Leptobos sten.-merlai- furtivus & $x$ & $x$ & $\mathrm{x}$ & & \\
\hline Stephanorhinus etruscus & $\mathrm{x}$ & $x$ & $x$ & & \\
\hline Leptobos etruscus & $?$ & $\mathrm{x}$ & $\mathrm{x}$ & & \\
\hline Enhydrictis ardea & $\mathrm{x}$ & $\mathrm{x}$ & $\mathrm{x}$ & ...... & \\
\hline Equus stenonis & $x$ & $x$ & $\mathrm{x}$ & $\mathrm{x}$ & \\
\hline Macaca sylvanus florentinus & $x$ & & $\mathrm{x}$ & $\mathrm{x}$ & \\
\hline Canis ex gr. C. etruscus & $x$ & $x$ & $\mathrm{x}$ & $\mathrm{x}$ & \\
\hline Sus strozzii & $x$ & $x$ & $x$ & $x$ & $?$ \\
\hline Lynx issiodorensis & & $\mathrm{x}$ & $\mathrm{x}$ & $\mathrm{x}$ & $?$ \\
\hline Vulpes cf. V. alopecoides & $x$ & $=$ & $\mathrm{x}$ & & $\mathrm{x}$ \\
\hline Megantereon cultridens - M. whitei & & $x$ & $\mathrm{x}$ & & $x$ \\
\hline Homotherium ex gr. H. crenatidens & & $\mathrm{x}$ & $\mathrm{x}$ & $\mathrm{x}$ & $x$ \\
\hline Mammuthus meridionalis & $x$ & $\mathrm{x}$ & $\mathrm{x}$ & $\mathrm{x}$ & $x$ \\
\hline Felis sylvestris lunensis & & $\mathrm{x}$ & & & \\
\hline Pseudodama nestii & & $\mathrm{x}$ & & & \\
\hline Eucladoceros dicranios- ctenoides & & $\mathrm{x}$ & $\mathrm{x}$ & & \\
\hline Ursus etruscus & & $\mathrm{x}$ & $\mathrm{x}$ & $\mathrm{x}$ & $?$ \\
\hline Pachycrocuta brevirostris & & $\mathrm{x}$ & $\mathrm{x}$ & $\mathrm{x}$ & $x$ \\
\hline Pantera ex gr. P. gombaszoegensis & & $\mathrm{x}$ & $\mathrm{x}$ & $\mathrm{x}$ & $x$ \\
\hline Canis arnensis & & ? & $\mathrm{x}$ & $\mathrm{x}$ & \\
\hline Martes sp. & & & $\mathrm{x}$ & & \\
\hline Praeovibos sp. & & & $\mathrm{x}$ & & \\
\hline Pannonictis nestii & & & $x$ & $\mathrm{x}$ & \\
\hline Lycaon falconeri & & - & $\mathrm{x}$ & $\mathrm{x}$ & \\
\hline Equus stehlini & & L & $\mathrm{x}$ & $\mathrm{x}$ & \\
\hline Leptobos ex gr. L. vallisarni & & [ & $\mathrm{x}$ & $\mathrm{x}$ & \\
\hline Cervalces gallicus & & & $\mathrm{x}$ & $\mathrm{x}$ & $?$ \\
\hline Pseudodama eurygonos- farnetensis & & & $\mathrm{x}$ & $\mathrm{x}$ & $x$ \\
\hline Equus altidens & Pliocene - & & $\mathrm{x}$ & $\mathrm{x}$ & $x$ \\
\hline Praemegaceros obscurus & Pleistocene & 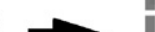 & & $x$ & \\
\hline Stephanorhinus cf. S. hundsheimensis & & & & $\mathrm{x}$ & $\mathrm{x}$ \\
\hline Megalovis sp. (= Ovibovini indet.) & Boundary & & & & $x$ \\
\hline Canis aff. C. arnensis (advanced) & & & & & $x$ \\
\hline Lycaon lycaonoides & & & ] & & $x$ \\
\hline Bison (Eobison) degiulii & & 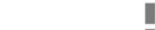 & & & $x$ \\
\hline Ursus sp. & & $=$ & & & ? \\
\hline Hippopotamus ex gr. H. antiquus & & 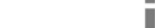 & $?$ & & $x$ \\
\hline Equus gr.bressanus- sussenbornensis & & & & & $x$ \\
\hline
\end{tabular}

Fig. 6. Distribution pattern of large-mammalian faunal units and taxa of the Middle and Late Villafranchian Mammal Age in the Italian peninsula. The correlation with small-mammal biochronological units is also indicated. The Pliocene-Pleistocene boundary is according to Aguirre and Pasini (1985). Explanations of symbols as in Fig. 3.

malezi and Dinaromys dalmatinus indicate the affinity of the northern eastern Italian areas with the Balkan province (Fig. 7).

The faunal composition of the following Farneta FU (i.e. at the localities of Cava Liberatori and Pietrafitta; Fig. 5) is similar to that of Tasso, but it records two important new occurrences: that of the megalocerine group, with the species Praemegaceros (= Megaceroides) obscurus (Abbazzi, 2004), and of the rhinocerotid Stephanorhinus cf. hundsheimensis (Alberdi et al., 1998; Zucchetta et al., 2003). At the same time many Villafranchian taxa are recorded for the last time in this unit. The occurrence of Microtus (Allophaiomys) ex gr. ruffoi, Microtus (Allophaiomys) chalinei and M. pusillus at Pietrafitta (Gentili et al., 1996) provide direct correlation of the unit with the Early Biharian (Figs. 1, 5-7).
The Cava Pirro assemblage indicates a further episode of faunal renewal and represents the last faunal unit of the Late Villafranchian, Pirro FU (De Giuli et al., 1987; Gliozzi et al., 1997) (Fig. 5). The most important find is the occurrence of a primitive bison (Bison (Eobison) degiulii), but also the occurrence of Lycaon lycaonoides (Martinez Navarro and Rook, 2003), and the spread of Hippopotamus, are worth mentioning (Fig. 6). Among the small mammals, the presence of $M$. (Allophaiomys) ex gr. ruffoi, with a more derived enamel differentiation pattern than that of Pietrafitta, is significant (Masini and Santini, 1991; Lippi et al., 1998). The Pirro FU also includes new insectivore taxa and the last find of the genus Hypolagus in Italy. The assemblage from the Soave Cava Sud, the type locality of Allophaiomys ruffoi is included in this unit (Figs. 5-7). 


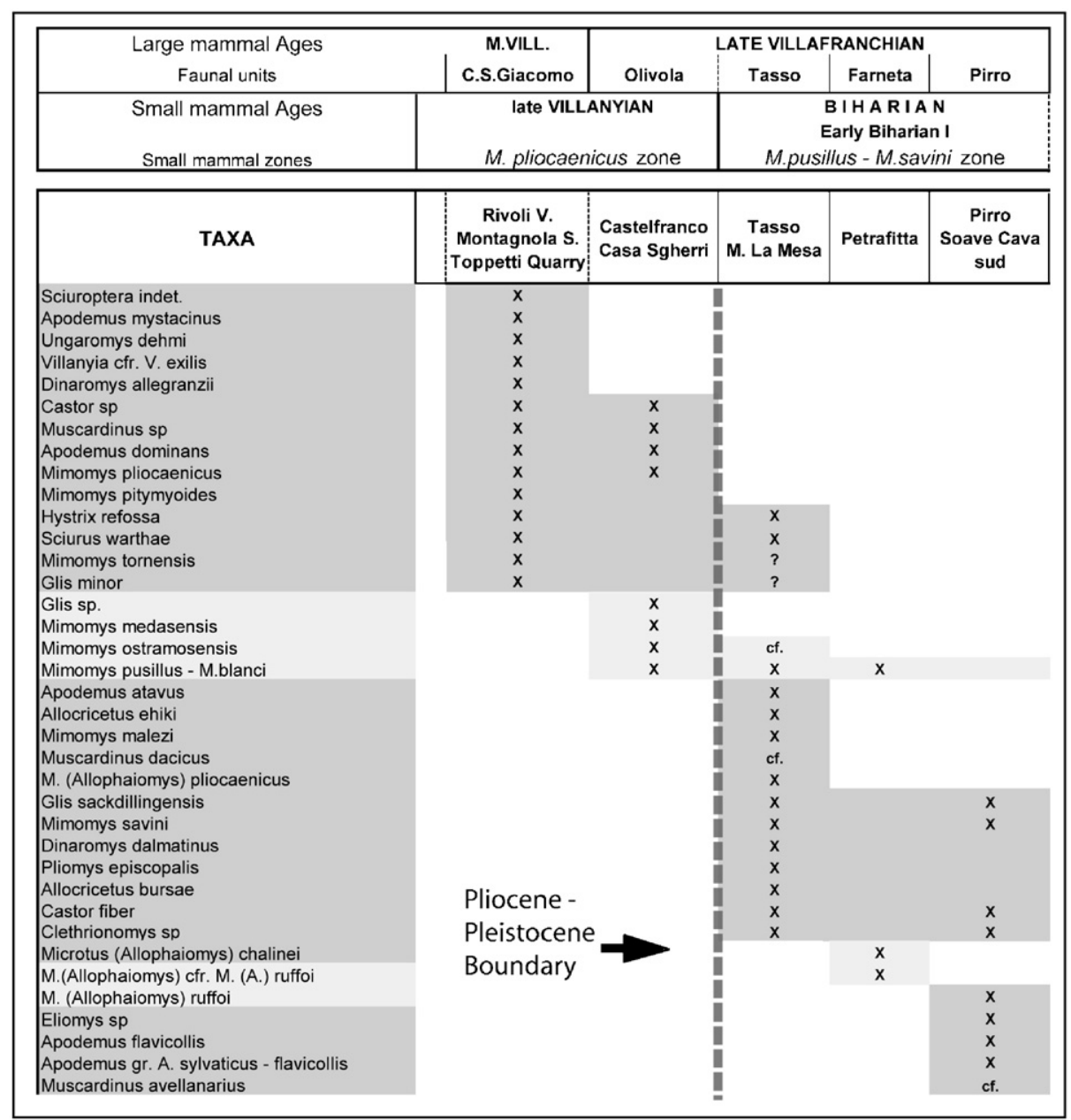

Fig. 7. Distribution pattern of rodent taxa of the Late Villanyian and Early Biharian Mammal Ages in the Italian peninsula. The correlation with largemammal biochronological units is also indicated. The Pliocene-Pleistocene boundary is according to Aguirre and Pasini (1985). Explanations of symbols as in Fig. 3.

The Monte la Mesa, Pietrafitta (Farneta), Cava Pirro, and Soave Cava Sud faunas are characterised by primitive Microtus (Allophaiomys) species. They represent a Late Biharian succession that is distinct from the subsequent small mammal faunas, in which Microtus (Allophaiomys) species with more evolved features occur. This older part of the Early Biharian is shown as 'Early Biharian I' in Figs. 1, 6-9.

The Tasso, Farneta, and Pirro FU record the Pleistocene part of the Late Villafranchian, an interval during which the faunas were gradually and still not completely displaced by the large mammals that characterise the following Galerian Mammal Age.

\section{The transition to glacial climates: Galerian, Late Biharian, and Early Toringian}

The climatic deterioration that began in the Middle Pliocene progressively depleted the flora. The rapid climatic alternation ( $41 \mathrm{ka}$ cycles) between moist and arid phases roughly corresponds to an alternation between vegetational assemblages of warm-temperate deciduous forests and vegetational assemblages of steppe and/or conifer forest (Bertini, 2003). The onset of the $100 \mathrm{ka}$ driven climatic fluctuations produced a more substantial variation, where xeric, cool to cold steppe vegetation alternates with deciduous forests (Bertini, 2003). A marked latitudinal cline, with predominant drier conditions in the southern part of the peninsula is also present, the regions east of the Apennines being drier than those on the western side (Sala, 2003).

The Colle Curti fauna (Central Apennine; Ficcarelli and Silvestrini, 1991; Abbazzi et al., 1998; Martinez Navarro and Rook, 2003; Gentili and Masini, 2005) represents the first faunal unit of the Galerian Mammal Age (Fig. 5). This fauna, characterised by the dominant occurrence of Hippopotamus, records the first finds of the megalocerine Praemegaceros (= Megaceroides) verticornis, and of Bison (Bison). Only two species of Arvicolids are present at Colle Curti, Pliomys lenki, which is its first occurrence in Italy, and Microtus (Allophaiomys) sp. The latter vole is characterised by a simple ACC morphology, fully comparable to M. (Allohaiomys) pliocaenicus and M. (Allophaiomys) ruffoi, together with an advanced, 
microtine-differentiated enamel (cf. also Markova, 2004). This fauna has been assigned to the Jaramillo Subchrone (Torre et al., 1996; Coltorti et al., 1998) (Figs. 1, 8, and 9).

The most important small-mammal locality correlated with Colle Curti is Monte Peglia (Umbria; Fig. 5) where Microtus (Allophaiomys) burgondiae, Microtus (Allophaiomys) nutiensis, M. savini, Mimomys blanci (a species strictly related to M. pusillus) and Ungaromys nanus occur (van der Meulen, 1973; Maul et al., 1998). The recent find of a small-mammal assemblage with a fully comparable composition to that from Monte Peglia is the locality of Castagnone (Piedmont; Fig. 5). It is normally magnetised and is referred to the Jaramillo Subchron (Giraudi et al., 2003). Castagnone allows a stronger chronological correlation of the Monte Peglia fauna and confirms the correlation of the Colle Curti FU with the upper part of the Early Biharian (Figs. 1, 8, and 9).

The Colle Curti FU and the later part of Early Biharian, as defined above, correspond to the beginning of the most important faunal change of the Pleistocene. During this

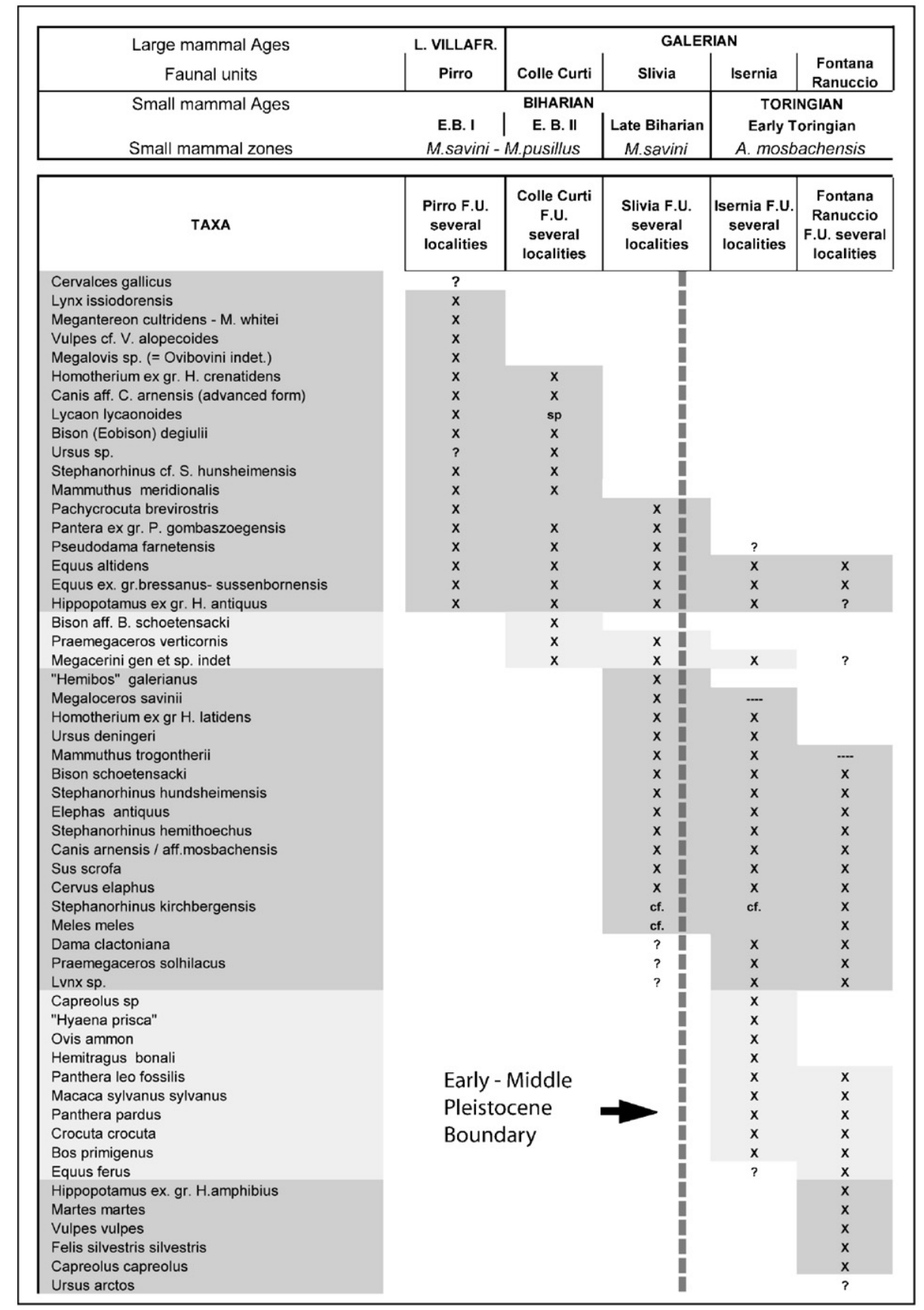

Fig. 8. Distribution pattern of large-mammalian faunal units and taxa of the late part of the Late Villafranchian and the Galerian Mammal Ages in the Italian peninsula. The correlation with small-mammal biochronological units is also indicated. Early-Middle Pleistocene boundary according to Richmond (1996). Explanations of symbols as in Fig. 3. 


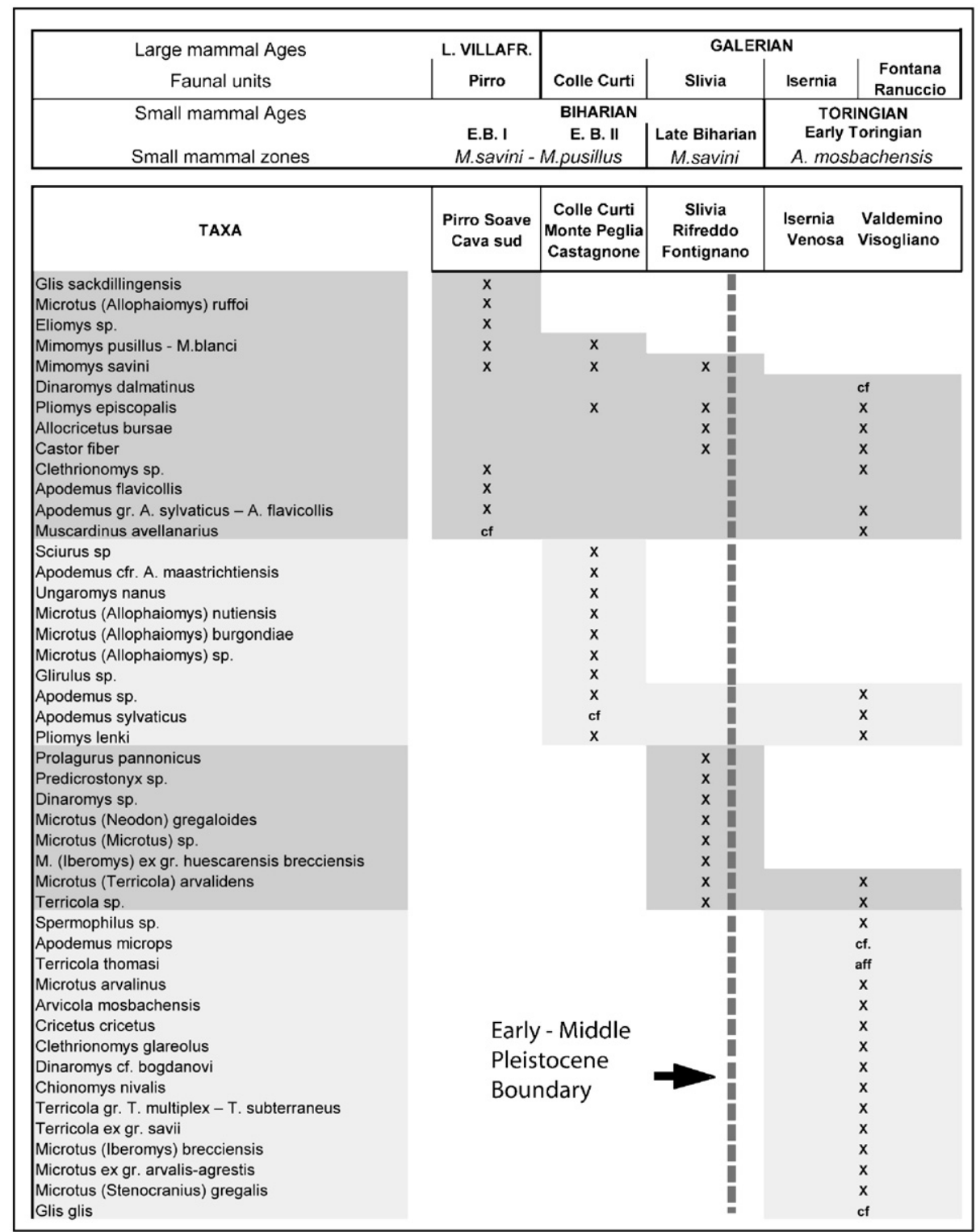

Fig. 9. Distribution pattern of rodent taxa of the Early to Late Biharian and Early Torinigian Mammal Ages in the Italian peninsula. The correlation with large-mammal biochronological units is also indicated. Early-Middle Pleistocene boundary according to Richmond (1996). Explanations of symbols as in Fig. 3.

renewal, the Villafranchian taxa became extinct, or in some cases gave rise to new species more adapted to arid, cold climates. Here, the Galerian forms appear together with some of the direct ancestors of the 'modern' faunal elements through a sequence of dispersal events (Figs. 8 and 9).

Colle Curti and the subsequent Slivia FU (Ambrosetti et al., 1979; Gliozzi et al., 1997) occur within the interval that apparently corresponds to the long transition between climates forced by the $41 \mathrm{ka}$ cycles and the later 'glacial' climate characterised by the alternation of pronounced glacial-interglacial periods modulated by the $100 \mathrm{ka}$ periodicity (Shackleton, 1995) (Fig. 1).

The strong fluctuations observed in the North Atlantic marine isotope record between Marine Isotope Stage (MIS) 25 and MIS 22 possibly represents a type of critical transition zone between the two climatic systems. The repeated climate oscillations changed the structure of the vegetational composition, and consequently also modified the structure of the faunal assemblages. Since this time, the faunal renewal apparently became more rapid with the dispersals of taxa with warm-humid and cold-steppe affinities during interglacial and glacial events, respectively. This process established a new assemblage of resident taxa, many of which disappeared during the extinction phase of the last glacial cycle (Weichselian, Würmian) or persist into the Holocene.

At the same time, the peninsula starts to play a more important role as a refuge area for temperate taxa during stadial phases, resulting in an increased faunal diversity. Finally, the climatic subdivision into two main zones, the Western Ligurian-Tyrrhenian and the Eastern Adriatic 
becomes more apparent. The southern peninsula possibly formed a third zone but it is still poorly defined.

Within the Slivia and the following Isernia faunal units the most important large-mammals events are: the spread of slender bison, Bison schoetensacki, of archaic forms of several recent species, such as the roe deer (Capreolus sp.), red deer (Cervus elaphus acoronatus), spotted hyaena (Crocuta crocuta, Ponte Galeria 2; Milli and Palombo, 2005), lion (Panthera leo fossilis), leopard Panthera pardus (Valdemino Cave, Liguria; Sala, 1992) and fallow deer (Dama clactoniana); and eventually of extinct species such as a primitive water buffalo (Hemibos galerianus; in Martınez Navarro and Palombo, 2004), the giant deer Praemegaceros solihachus (Abbazzi, 2004), the steppe elephant (Mammuthus trogontherii), the straight-tusked elephant (Elephas antiquus) the Merk's rhinoceros (Stephanorhinus kirchbergensis), and Deninger's bear (Ursus deningeri) (Figs. 8 and 9).

The Slivia FU correlates directly with the Late Biharian based on the occurrence of Microtus (Stenocranius) and Microtus (Terricola), associated with M. savini. The Rifreddo locality in the San Lorenzo succession (Sant'Arcangelo Basin, Basilicata; Masini et al., 2005; Sabato et al., 2005; Fig. 5) has yielded a slightly younger small-mammal fauna, equated to the early part of Brunhes Chron (Sabato et al., 2005), which records the first occurrence of Microtus (Iberomys), a taxon that persisted into the Late Middle Pleistocene in Southern Italy, and of Microtus (Terricola) arvalidens (Fig. 9).

The archaeological site Isernia La Pineta (Molise; Fig. 5), which is the type locality of the Isernia FU, has yielded the Oldest Toringian fauna in Italy, in which, however, the 'marker' vole Arvicola mosbachensis still retains a small percentage of molars with incipient roots. Important large-mammal taxa present include Praemegaceros (= Megaceroides) solilhacus, the thar Hemitragus bonali, D. clactoniana and Capreolus sp., while significant small-mammal taxa include: Pliomys episcopalis, Pliomys lenki, Microtus aff. arvalis, Microtus (Iberomys) brecciensis and M. (Terricola) ex gr. multiplex-subterraneus (Sala, 1996a; Koenigswald and van Kolfschoten, 1996). The Grotta Valdemino fauna (Liguria; Fig. 5) is a good example of a 'warm assemblage' of the Early Toringian in which a dominant small-sized $M$. (Iberomys) brecciensis is associated to Microtus (Terricola) sp. (Sala, 1992; Nocchi and Sala, 1997). The thick archaeological sequence of Visogliano Shelter (Carso Triestino, Friuli Venezia Giulia; Fig. 5) in which a warm to cool climatic fluctuation is recorded, has yielded a typical A. mosbachensis and represents a Middle-Late Galerian assemblage. In this site skeletal remains referred to 'archaic' Homo sapiens have also been recovered (Abbazzi et al., 2000). Here, the whole stratigraphical sequence is dominated by Microtus cf. arvalinus, the endemic vole Dinaromys cf. bogdanovi and the red deer $C$. elaphus acoronatus. Crocidura, $M$. (Terricola) cf. arvalidens, Macaca, and fairly abundant Clacton fallow deer D. clactoniana occur in the temperate climate lower levels (Abbazzi et al., 2000). Significant occurrences within the upper cooler climate levels are those of the tundra vole Microtus (Stenocranius) gregalis, the pika Ochotona sp., the suslik Spermophilus sp., and the argali Ovis ammon (Figs. 8 and 9).

During the interval spanning from Colle Curti-Monte Peglia to Isernia, the evolutionary radiation of genus Microtus (sensu lato) became evident in the fossil record. Starting with diversified Microtus (Allophahiomys) species, this genus, with his sub-generic branches, became dominant among voles in the Italian faunal assemblages. Meanwhile, the rooted arvicolids become rare and progressively disappear except for Clethrionomys and Dinaromys; the latter still surviving in a restricted area of the Balkans. The last extinction event is that of $P$. lenki at the beginning of the Late Pleistocene (MIS 5e; see Gibbard and van Kolfschoten, 2004, for a discussion on this chronostratigraphical boundary).

The greatest number of new occurrences of large mammals is reported at Slivia FU (Fig. 8), while the greater renewal impulse for small mammals corresponds to the Isernia FU (Fig. 9). This shift in first occurrences could be due to the limited representation (only two significant localities, Slivia and Rifreddo) of Late Biharian smallmammal faunas, while the Slivia FU includes several finds of large mammals from Ponte Galeria (Ponte Galeria 2; Petronio and Sardella, 1999; Milli et al., 2004; Milli and Palombo, 2005).

Concerning the Early-Middle Pleistocene boundary, during the last years several proposals have been presented (i.e. Ruggieri et al., 1984; Cita and Castradori, 1994; Capraro et al., 2004; Ciaranfi and D'Alessandro, 2005). Nowadays, as mentioned in the Introduction, the proposal of Richmond (1996) has acquired more approval.

From what has been previously reported on the biochronological patterns of small and large mammals in Italy, the Early Middle Pleistocene boundary is placed within the Late Biharian for small mammals, and within the Slivia FU for large mammals (Figs. 1, 8 and 9). However, a boundary placed close to MIS 25 would be more precisely approximated by faunal patterns, since it would roughly coincide with the transitions from the Early to the Late Biharian and from the Colle Curti to the Slivia faunal units, for small and large mammals, respectively.

\section{Post-Galerian}

At the end of the Galerian, possibly c. $0.4-0.3 \mathrm{ma}$, many taxa that characterise this Mammal Age disappear and the recent mammalian assemblage begins. The Post-Galerian (Aurelian; in Gliozzi et al., 1997) represents the later part of the Middle Pleistocene and the Late Pleistocene during which the strongest climatic fluctuations occurred, probably corresponding to MIS 10-MIS 2 (Fig. 1). The PostGalerian fauna, however, is depleted by several terminal extinction events of very large taxa (the woolly mammoth, the woolly rhinonoceros, the giant deer, several large 
carnivores). These extinctions occurred mainly during the Würmian Stage, as a response to climatic effects and, according to some authors, human action. During the Holocene, the spread of human cultures in the Mediterranean regions from the Neolithic Period onwards caused modifications of the environment, influenced the dispersal patterns and greatly changed the natural assemblages by the introduction of exotic species.

\section{Acknowledgements}

We would sincerely like to thank Dr. Laura Abbazzi and Massimiliano Ghinassi who kindly gave information on the new M. polonicus finds, described in Ghinassi et al. (2005). Many thanks to the referees who motivated us to revise and complete some parts of the work, and especially to Prof. P. Gibbard who kindly revised and greatly improved the quality of the manuscript. The work is supported by grants of the Italian Ministry for University and for Scientific and Technological Research (M.I.U.R.-Cofin 2003-2004) and Athenaeum grants 2004-2005, University of Palermo (F. Masini), and University of Ferrara (B. Sala).

\section{References}

Abbazzi, L., 2004. Remarks on the validity of the generic name Praemegaceros Portis 1920, and an overview on Praemegaceros species in Italy. Rendiconti Accademia dei Lincei-Scienze Fisiche Matematiche Naturali, Series 9 (15), 115-132.

Abbazzi, L., Masini, F., Ficcarelli, G., Torre, D., 1998. Arvicolids finds (Rodentia, Mammalia) from the early Galerian of Colle Curti (Umbro-Marchean Apennines, Central Italy). Acta Zoologica Cracoviensia 41, 133-142.

Abbazzi, L., Fanfani, F., Ferretti, M.P., Rook, L., Cattani, L., Masini, F., Mallegni, F., Negrino, F., Tozzi, C., 2000. New human remains of archaic homo sapiens and lower palaeolithic industries from visogliano (Dusino Aurisina, Trieste, Italy). Journal of Archaeological Science 27, 1173-1186.

Aguirre, E., Pasini, G., 1985. The plio-pleistocene boundary. Episodes 8, 116-120.

Alberdi, M.T., Caloi, L., Palombo, M.R., 1998. Large mammal associations from the early pleistocene: Italy and Spain. Mededelingen Nederlands Instituut voor Toegepaste Geowetenschappen TNO 60, 521-532.

Albianelli, A., Magi, M., Mazzini, M., Napoleone, G., 2002. The plio-pleistocene boundary in the Northern Apennine continental deposits as defined by the Faella magnetostratigraphic section in the Upper Valdarno. Bollettino della Società Geologica Italiana 1, 473-479 (special volume).

Ambrosetti, P., Bartolomei, G., De Giuli, C., Ficcarelli, G., Torre, D., 1979. La breccia ossifera di Slivia (Aurisina-Sistiana) nel Carso di Trieste. Bollettino della Società Paleontologica Italiana 18, 207-220.

Azzaroli, A., 1977. The Villafranchian stage in Italy and the plio-pleistocene boundary. Giornale di Geologia 41, 61-79.

Azzaroli, A., De Giuli, C., Ficcarelli, G., Torre, D., 1988. Late pliocene to early mid-pleistocene mammals in Eurasia: faunal succession and dispersal events. Palaeogeography Palaeoclimatology Palaeoecology 66, 77-100.

Benvenuti, M., Dominici, S., Rook, L., 1995. Inquadramento stratigrafico-deposizionale delle faune a mammiferi villafranchiane (unita faunistiche Triversa e Monopoli) del Valdarno Inferiore nella zona a sud dell'Arno (Toscana). Il Quaternario 8, 457-464.
Bertini, A., 2003. Early to middle pleistocene changes of the Italian flora and vegetation in the light of a chronostratigraphic framework. Il Quaternario 16, 19-36.

Berzi, A., Hutchison, J.H., Lindsay, E., Michaux, J., 1967. The Arondelli local fauna, an assemblage of small vertebrates from villafranchian stage near Villafranca d'Asti, Italy. Giornale di Geologia 35, 1-4.

Capraro, L., Rio, D., Sprovieri, R. Channel, J.E.T., Vai, G.B., 2004. A candidate section for defining the lower/middle pleistocene boundary. In: 32nd International Geological Congress, Florence, vol. 25(16) 2004, p. 1137.

Cavallo, O., Sen, S., Rage, J.C., Gaudant, J., 1993. Vertébrés messiniens du Faciès à congéries de Ciabòt Cagna, Corneliano d'Alba (Piémont, Italie). Rivista Piemontese di Storia Naturale 14, 3-22.

Ciaranfi, N., D'Alessandro, A., 2005. Overview of the Montalbano Jonico area and section: a proposal for a boundary stratotype for the lower-middle pleistocene, Southern Italy Foredeep. Quaternary International 131, 5-10.

Ciaranfi, N., D'Alessandro, A., Marino, M., 1997. A candidate section for the lower-middle pleistocene boundary (Apennine Foredeep, South Italy). In: Proceedings of the 30th International Geological Congress, vol. 11 , pp. 201-211.

Ciaranfi, N., Brilli, M., Capotondi, C., D'Alessandro, A., Girone, A., La Perna, R., Maiorano, P., Marino, M., Stefanelli, S., 2004. The early/ middle pleistocene transition at the Montalbano Jonico section (Southern Italy). In: 32nd International Geological Congress, Florence, vol. 252(2), 2004, p. 1135.

Cita, M.B., Castradori, D., 1994. Workshop on marine sections from the Gulf of Taranto (Southern Italy) usable as potential stratotypes for the GSSP of the Lower, Middle and Upper Pleistocene. Il Quaternario 7, 677-692.

Coltorti, M., Albianelli, A., Bertini, A., Ficcarelli, G., Laurenzi, M.A., Napoleone, G., Torre, D., 1998. The Colle Curti mammal site in the Colfiorito area (Umbria-Marchean Apennine, Italy): geomorphology, stratigraphy, paleomagnetism and palynology. Quaternary International 47/48, 107-116.

Coltorti, M., Feraud, G., Marzoli, A., Peretto, C., Ton-That, T., Voinchet, P., Bahain, J.-J., Minelli, A., Thun Hohenstein, U., 2005. New ${ }^{40} \mathrm{Ar} /{ }^{39} \mathrm{Ar}$, stratigraphic and palaeoclimatic data on the Isernia $\mathrm{La}$ Pineta lower palaeolithic site, Molise, Italy. Quaternary International $131,11-22$.

De Giuli, C., Vai, G.B., 1988. Fossil Vertebrates of the Lamone Valley Romagna Apennines. Field Trip Guidebook, Litografica ed. Faenza, pp. 1-78.

De Giuli, C., Ficcarelli, G., Mazza, P., Torre, D., 1984. Confronto fra le successioni marine e continentali del Pliocene e Pleistocene inferiore in Italia e nell'area mediterranea. Bollettino della Società Paleontologica Italiana 22, 323-328.

De Giuli, C., Masini, F., Torre, D., 1987. The latest Villafranchian faunas of Italy: the Pirro Nord fauna (Apricena, Gargano). Paleontographia Italica 74, 51-62.

Fejfar, O., 2001. The Arvicolids from Arondelli-Triversa: a new look. Bollettino della Società Paleontologica Italiana 40, 185-193.

Ficcarelli, G., Silvestrini, M., 1991. Biochronologic remarks on the local fauna of Colle Curti (Colfiorito Basin, Umbrian-Marchean Apennine, Central Italy). Bollettino della Società Paleontologica Italiana 30, 197-200.

Gentili, S., Masini, F., 2005. An outline of Italian Leptobos and a first sight on Leptobos aff. vallisarni from Pietrafitta (early pleistocene, Perugia). Quaternarie, Hors Series 2, 81-89.

Gentili, S., Abbazzi, L., Masini, F., Ambrosetti, P., Argenti, P., Torre, D., 1996. Voles from the early pleistocene of Pietrafitta (Central Italy, Perugia). Acta Zoologica Cracoviensia 39, 185-199.

Ghinassi, M., Magi, M., Sagri, M., Singer, B.S., 2004. Arid climate $2.5 \mathrm{Ma}$ in the plio-pleistocene Valdarno Basin (Northern Apennines, Italy). Palaeogeography, Palaeoclimatology, Palaeoecology 207, 37-57.

Ghinassi, M., Abbazzi, L., Esu, D., Gaudant, J., 2005. Facies analisys, stratigraphy and Palaeontology (Molluscan and vertebrates) in the upper pliocene sandy flood-basin deposits of the Upper Valdarno 
Basin (Northern Apennines). Rivista Italiana Paleontologia Stratigrafica 111, 463-483.

Gibbard, P., van Kolfschoten, T., 2004. The pleistocene and holocene epochs. In: Gradstein, F., Ogg, J., Smith, A. (Eds.), Geological Time Scale 2004. Cambridge University Press, Cambridge, pp. 441-452.

Giraudi, C., Mottura, A., Sala, B., Siori, M.S., Bormioli, D., 2003. The Castagnone site (Cerrina Valley, Monferrato Hills, NW Italy): early Pleistocene sedimentary record and biochronology. Rivista Italiana di Paleontologia e Stratigrafia 109, 517-526.

Girotti, O., Capasso Barbato, L., Esu, D., Gliozzi, E., Kotsakis, T., Martinetto, E., Petronio, C., Sardella, R., Squazzini, E., 2003. The section of Torre Picchio (Terni, Umbria, Central Italy): a Villafranchian site rich in mammals, molluscs, ostracods and plants. Rivista Italiana di Paleontologia e Stratigrafia 109, 77-98.

Gliozzi, E., Abbazzi, L., Argenti, P., Azzaroli, A., Caloi, L., Capasso Barbato, L., Di Stefano, G., Esu, D., Ficcarelli, G., Girotti, O., Kotsakis, T., Masini, F., Mazza, P., Mezzabotta, C., Palombo, M.R., Petronio, C., Rook, L., Sala, B., Sardella, R., Zanalda, E., Torre, D., 1997. Biochronology of selected mammals, molluscs and ostracods from the middle pliocene to the late pleistocene in Italy. The state of the art. Rivista Italiana di Paleontologia e Stratigrafia 103, 369-388.

Gradstein, F., Ogg, J., Smith, A. (Eds.), 2004. A Geologic Time Scale 2004. Cambridge University Press, Cambridge, 589pp.

Koenigswald, W., van Kolfschoten, T., 1996. The Mimomys-Arvicola boundary and the enamel thickness quotient (SDQ) of Arvicola as stratigraphic markers in the middle pleistocene. In: Turner, C. (Ed.), The Early Middle Pleistocene in Europe. Balkema, Rotterdam, pp. 211-226.

Kotsakis, T., Abbazzi, L., Angelone, C., Argenti, P., Barisone, G., Fanfani, F., Marcolini, F., Masini, F., 2003. Plio-pleistocene biogeography of Italian mainland micromammals. Deinsea 10, 313-342.

Lindsay, E.H., 1990. The setting. In: Lindsay, E.H., Fahlbush, V., Mein, P. (Eds.), European Neogene Mammalian Chronology. NATO ASI Series A Life Sciences, vol. 180, Plenum Press, New York, pp. 1-14.

Lindsay, E.H., Opdyke, N.O., Johnson, N.M., 1980. Pliocene dispersal of the horse Equus and late Cenozoic mammalian dispersal events. Nature 287, 135-138.

Lippi, P., Masini, F., Maul, L., Abbazzi, L., 1998. Evolutionary changes of enamel differentiation in pleistocene Mediterranean and middle European populations of Microtus (Rodentia, Arvicolidae). Paludicola 2, 50-61.

Marchetti, M., Parolin, K., Sala, B., 2000. The Biharian fauna from Monte La Mesa (Verona, northeastern Italy). Acta Zoologica Cracoviensia 43, 79-105.

Marcolini, F., 2002. Continental Lower Valdarno rodent biochronology and two new methods for the systematics of Mimomys (Arvicolidae, Rodentia). Ph.D. Dissertation, University of Pisa, 165pp.

Marcolini, F., 2003. Continental Lower Valdarno rodent biochronology and two new methods for the systematics of Mimomys (Arvicolidae, Rodentia). Atti Società Toscana Scienze Naturali, Memorie 108, 129-135.

Marcolini, F., Bonadonna, F.P., Kotsakis, T., Mazza, P., Zanchetta, G., 2000. Preliminary data on the micro- and macromammal remains from Casa Sgherri Lower Valdarno (Tuscany, Central Italy). Bollettino della Società Paleontologica Italiana 39, 243-252.

Markova, A.K., 2004. Eastern European rodent (Rodentia, Mammalia) faunas from the early-middle pleistocene transition. Quaternary International 131, 71-77.

Martınez Navarro, B., Palombo, M.R., 2004. Occurrence of the Indian genus Hemibos (Bovini, Bovidae, Mammalia) at the early-middle pleistocene transition in Italy. Quaternary Research 61, 314-317.

Martinez Navarro, B., Rook, L., 2003. Gradual evolution in the African hunting dog lineage. Systematic implications. Comptes-Rendus de l'Académie des Sciences, Paleovol 2, 695-702.

Masini, F., 1989. I bovini villafranchiani in Italia. Ph.D. dissertation in Palaeontology, 2 volumes, Modena.
Masini, F., Santini, G., 1991. Microtus (Allophaiomys) from Cava Pirro (Apricena, Gargano) and other italian localities. Bollettino della Società Paleontlogica Italiana 30, 355-380.

Masini, F., Torre, D., 1987. Review of the Villafranchian Arvicolids of Italy. Geologica Romana 26, 127-133.

Masini, F., Ficcarelli, G., Torre, D., 1995. Late Villafranchian and the earliest Galerian mammal Faunas from some intermontane basins of north-central Italy. Memorie della Società Geologica Italiana 48, 381-389.

Masini, F., Giannini, T., Abbazzi, L., Fanfani, F., Delfino, M., Maul, L.C., Torre, D., 2005. A latest Biharian vertebrate fauna from the lacustrine succession of San Lorenzo (Santarcangelo Basin) Basilicata Italy. Quaternary International 131, 79-93.

Maul, L., Masini, F., Abbazzi, L., Turner, A., 1998. The use of different morphometric data for absolute age calibration of some south- and middle European arvicolid populations. Palaeontographia Italica 85, $111-151$

Mazza, P., Rustioni, M., 1996. The Turolian fossil artiodactyls from Scontrone (Abruzzo, Central Italy) and their paleoecological and paleogeographical implications. Bollettino della Società Paleontologica Italiana 35, 93-106.

Mazza, P., Bertini, A., Magi, M., 2004. The Late Pliocene site of Poggio Rosso (Central Italy): taphonomy and palaeoevironment. Palaios 19, 227-248.

van der Meulen, A.J., 1973. Middle Pleistocene smaller mammals from the Monte Peglia. (Orvieto Italy) with special reference to the phylogeny of Microtus (Arvicolidae, Rodentia). Quaternaria 17, 1-144.

Michaux, J., 1970. Les rongeurs (Arvicolidés, Muridés and Gliridés) de la localité Arondelli a Villafranca d'Asti (Italie). Palaeontographia Italica 66, 67-80.

Milli, S., Palombo, M.R., 2005. The high-resolution sequence stratigraphy and the mammal fossil record: a test in the middle-upper pleistocene deposits of the Roman Basin (Latium, Italy). Quaternary International 126-128, 251-270.

Milli, S., Palombo, M.R., Petronio, C., Sardella, R., 2004. The middle Pleistocene deposits of the Roman Basin (Latium, Italy): an integrated approach of mammal biochronology and sequence stratigraphy. Rivista Italiana di Paleontologia e Stratigrafia 110, 557-567.

Napoleone, G., Albianelli, A., Azzaroli, A., Bertini, A., Magi, M., Mazzini, M., 2003. Calibration of the Upper Valdarno Basin to the plio-pleistocene for correlating the Apennine continental sequences. Il Quaternario 16, 131-166.

Nocchi, G., Sala, B., 1997. Oryctolagus burgi n. sp. (Mammalia: Lagomorpha) from the middle pleistocene levels of Grotta Valdemino (Borgio Verezzi, Savona, north-west Italy). Paleontologia i Evolució 30-31, 19-38.

Palombo, M.R., Azanza, B., Alberdi, M.T., 2002. Italian mammal biochronology from the latest miocene to the middle pleistocene: a multivariate approach. Geologica Romana 36, 335-368.

Petronio, C., Sardella, R., 1999. Biochronology of the Pleistocene mammal fauna from Ponte Galeria (Rome) and remarks on the Middle Galerian faunas. Rivista Italiana di Paleontologia e Stratigrafia $105,155-164$

Petronio, C., Argenti, P., Caloi, L., Esu, D., Girotti, E., Sardella, R., 2002. Updating Villafranchian mollusc and mammal fauna of Umbria and Latium (Central Italy). Geologica Romana 36, 369-387.

Richmond, G.M., 1996. The INQUA approved provisional lower-middle pleistocene boundary. In: Turner, C. (Ed.), The Early Middle Pleistocene in Europe. Balkema, Rotterdam, pp. 226-319.

Rio, D., Sprovieri, R., Di Stefano, E., 1994. The Gelasian stage: a proposal of a new chronostratigraphic unit of the pliocene series. Rivista Italiana di Paleontologia e Stratigrafia 100, 103-124.

Rio, D., Sprovieri, R., Castradori, D., Di Stefano, E., 1998. The Gelasian stage (upper pliocene): a new unit of the global standard chonostratigraphic scale. Episodes 21, 82-87.

Rio, D., Premoli Silva, I., Capraro, L., 2003. The geologic time scale and the Italian stratigraphic record. Episodes 26, 259-263. 
Rook, L., Masini, F., 1990. Prolagus from the Upper Valdarno (faunal associations of the Olivola and Tasso units, Late Villafranchian). Bollettino della Società Paleontologica Italiana 29, 357-360.

Rook, L., Torre, D., 1996. The wolf event in western Europe and the beginning of the Late Villafranchian. Neues Jahrbuch für Geologie und Paläeontologie Monatshefte 8, 495-501.

Rook, L., Abbazzi, L., Engesser, B., 1999. An overview on the Italian miocene land mammal faunas. In: Agustì, J., Rook, L., Andrews, P., (Eds.), 'Hominoid Evolution and Climatic Change in Europe. The Evolution of Neogene Terrestrial Ecosystems in Europe, vol. I. Cambridge, pp. 191-204.

Rook, L., Mazza, P., Rustioni, M., Torre, D., 2000. Lands and endemic mammals in the late miocene of Italy: paleogeographic outlines of Tyrrhenian and Adriatic areas between 11-9 and 7-4 Ma. European Science Foundation. Environments and Ecosystem Dynamics of the Eurasian Neogene (EEDEN) 'State of the Art' Workshop, Lyon, France, 16-18 November 2000. Available at: 〈http://www.esf.org/esf_ genericpage.php?print $=$ landlanguage $=0$ andsection $=2$ anddomain $=$ 3andgenericpage $=124\rangle$.

Ruggieri, G., Rio, D., Sprovieri, R., 1984. Remarks on the chronostratigraphic classifications of lower pleistocene. Bollettino della Società Geologica Italiana 103, 251-259.

Sabato, L., Bertini, A., Albianelli, A., Napoleone, G., Pieri, P., 2005. The lower and middle pleistocene geologic record of the San Lorenzo lacustrine succession in the Sant'Arcangelo Basin (Southern Apennines, Italy). Quaternary International 131, 59-69.

Sala, B., 1992. I mammiferi del Quaternario italiano. In: Tugnoli, C. (Ed.), I segni del tempo-Memoria delle origini ed icone del primordiale. Atti del corso di aggiornamento per personale docente, Trento, pp. 209-227.

Sala, B., 1996a. Gli animali del giacimento di Isernia La Pineta. In: Peretto, C. (Ed.), I reperti paleontologici del giacimento paleolitico di Isernia La Pineta. Cosmo Iannone ed., Isernia, pp. 25-49.

Sala, B., 1996b. Dinaromys allegranzii n. sp. (Mammalia, Rodentia) from Rivoli Veronese (northeastern Italy) in a Villanyian association. Acta Zoologica Cracoviensia 39, 469-472.
Sala, B., 2003. L'Italia del Nord-Est, ponte fra il Bacino Pannonico e il Mediterraneo occidentale. Atti in commemorazione di Edoardo Semenza, Università di Ferrara, pp. 203-208.

Sala, B., Masini, F., 2004. The late pliocene and pleistocene small mammal chronology in the Italian Peninsula. In: 32nd IGC, Florence, 20-28 August. Scientific sessions: abstracts (part 2), p. 1137.

Sala, B., Masini, F., 2006. The late Pliocene and Pleistocene small mammal chronology in the Italian peninsula. Quaternary International, this issue, doi:10.1016/j.quaint.2006.09.008.

Sala, B., Masini, F., Torre, D., 1994. Villanyian arvicolids from Rivoli Veronese, a karst fissure in the Adige Valley, northeastern Italy. Bollettino della Società Paleontologica Italiana $33,1-9$.

Sardella, R., Angelone, C., Barisone, G., Bedetti, C., Di Canzio, E., Marcolini, F., Squazzini, E., 2003. Italian plio-pleistocene mammal biochronology and correlation with marine sequences: three case studies. Il Quaternario 16, 15-20.

Shackleton, N.J., 1995. New data on the evolution of Pliocene climatic variability. In: Vrba, E.S., Denton, G.H., Partridge, T.C., Burckle, L.H. (Eds.), Paleoclimate and Evolution, with Emphasis on Human Origins. Yale University Press, New Haven, CT and London, pp. 242-248.

Torre, D., 1985. Mimomys savini and Arvicola cantiana in the Upper Valdarno (Italy). Eclogae Geologicae Helvetiae 78, 715-718.

Torre, D., Albianelli, A., Azzaroli, A., Ficcarelli, G., Magi, M., Napoleone, G., Sagri, M., 1993. Paleomagnetic calibration of late Villafranchian mammalian faunas from the Upper Valdarno, Central Italy. Memorie della Società Geologica Italiana 49, 344-355.

Torre, D., Albianelli, A., Bertini, A., Ficcarelli, G., Masini, F., Napoleone, G., 1996. Paleomagnetic calibration of plio-pleistocene mammal localities in central Italy. Acta Zoologica Cracoviensia 39, 559-570.

Zucchetta, G., Gentili, S., Pavia, M., 2003. A new early pleistocene bird association from Pietrafitta (Perugia, Central Italy). Rivista Italiana di Paleontologia e Stratigrafia 109, 527-538. 